\title{
Evaluation of Teachers' Performance Based on Age Group in Implementing Learning Process in Central Kalimantan
}

\author{
Joni Bungai ${ }^{1}$, Indra Perdana ${ }^{2}$ \\ ${ }^{1}$ Management of Education, Primary School Teacher Education, \\ State University of Palangka Raya \\ ${ }^{2}$ Indonesian Language and Literature Education Study Program, \\ State University of Palangka Raya \\ Email: jbungai@gmail.com
}

\begin{abstract}
The quality learning process can not be separated from the role of teachers as an educator. The Older teachers can be seen with their commitment to students. Younger teachers usually cultivate students' curiosity and interest in learning. Teachers recognize and try to fulfill their responsibilities to their students. This study aims to evaluate the performance of elementary school teachers by age group in implementing the learning process. This evaluation research used the 360 Degree Performance Appraisal Model. This evaluation model aims to measure the performance of teachers in accordance with predetermined standards or performance criteria. Assessment of teachers' performance was done by multi-assessors. The goal of this study is to identify the teacher's performance in conducting the learning process based on group age. Performance of teachers in opening lessons mostly were still lacking in providing student learning motivation contextually according to the benefits and application of teaching materials in everyday life. In the core learning activities, in the elaboration section, teachers did not provide opportunities for students to express and actualize themselves through meaningful activities and works
\end{abstract}

\section{Keywords: Teachers’ performance, Group Age, Learning Process}

\section{BACKGROUND}

Quality teaching process cannot be separated from the role of teachers as educators. Teachers are the center of learning and the key to the learning process. Many research said that young teachers much better in the learning process than older teachers [1,2]. Older teachers can be seen with their commitment to students. Younger teachers usually cultivate students' curiosity and interest in learning $[3,4,5]$. Teachers are the most influential component in achieving quality learning and education process. In the learning system, teachers become an inseparable part of the process of achieving educational goals. Without teachers, education will not function properly [6]. Therefore, the success of the learning process is determined by the ability of the teacher in implementing the learning process [7, 8]. Implementation of the learning process is the execution of the learning plan which includes preliminary, core, and closing activities. In the preliminary activities, teachers are required to (a) prepare students psychologically and physically to follow the learning process, (b) 
motivate students' learning contextually according to the benefits and application of teaching materials in everyday life, by providing examples of local, national, and international comparisons, and adapted to the characteristics and levels of the students, (c) ask questions that relate prior knowledge to the material to be studied, (d) explain the learning objectives or basic competencies to be achieved and (e) communicate the material coverage and explain activity description according to the curriculum [9].

The core activities is a learning process to achieve learning objectives. Learning activities are interactive, inspirational, fun, challenging, motivate students to participate actively, and provide sufficient space for initiative, creativity, and independence according to the talents, interests, and physical and psychological development of students. The core activities use methods tailored to the characteristics of students and subjects, which may include exploration, elaboration and confirmation processes [10].

In closing activities, teachers with students conduct reflections to evaluate: (a) the whole set of learning activities and results obtained to further jointly discover the direct or indirect benefits of the learning outcomes that have taken place, (b) Provide feedback on the learning process and outcomes, (c) conduct follow-up activities in the form of assignments, both individual and group tasks and (d) inform the lesson plan for subsequent meetings.

Teachers' performance assessment is basically a process of comparing the actual performance with the ideal performance to determine the level of success of teachers in carrying out their duties within a certain period [11]. Teachers' performance assessment is a reference for schools/madrasah to establish career development and teacher promotion. For teachers, teachers' performance appraisals are a guideline for knowing the elements of performance assessed and as a means to assess the strengths and weaknesses of individuals in order to improve the quality of their performance. Teacher's performance can be known by looking at how a teacher carried out learning activities, and by assessing learning outcomes [12].

This study focused on the performance of elementary school teachers in implementing the learning process by age group. Evaluation of teachers' performance based on age group was conducted, based on a study in which the teacher competency test result indicated that there was a decrease of competence in teacher aged 41 years old $[13,14]$. In addition, the result of the evaluation on the performance of these teachers can depict the performance of teachers in implementing the learning process [15].

\section{RESEARCH METHODS}

This study is a qualitative research evaluation (evaluation research). The model used is 360-degree performance evaluation (360 Degree Performance Appraisal Model) [16]. In general, this evaluation model aims to measure whether the performance of teachers is in accordance with predetermined standards or performance criteria.

This study was conducted to all elementary school teachers located in Central Kalimantan. Data were collected using teacher teachers' performance appraisal was done by multiple assessors, in other words, assessments were made by several people. Assessors were School Supervisors, Principals, and Teacher Friends. In the 
use of 360-degree models, the identity of the appraiser and the valuable were concealed so that the results of the assessment can be more accurate because the assessor would not feel burdened due by affecting the assessment results will affect the assessors and assessed teachers. The design of this study is illustrated as shown below.

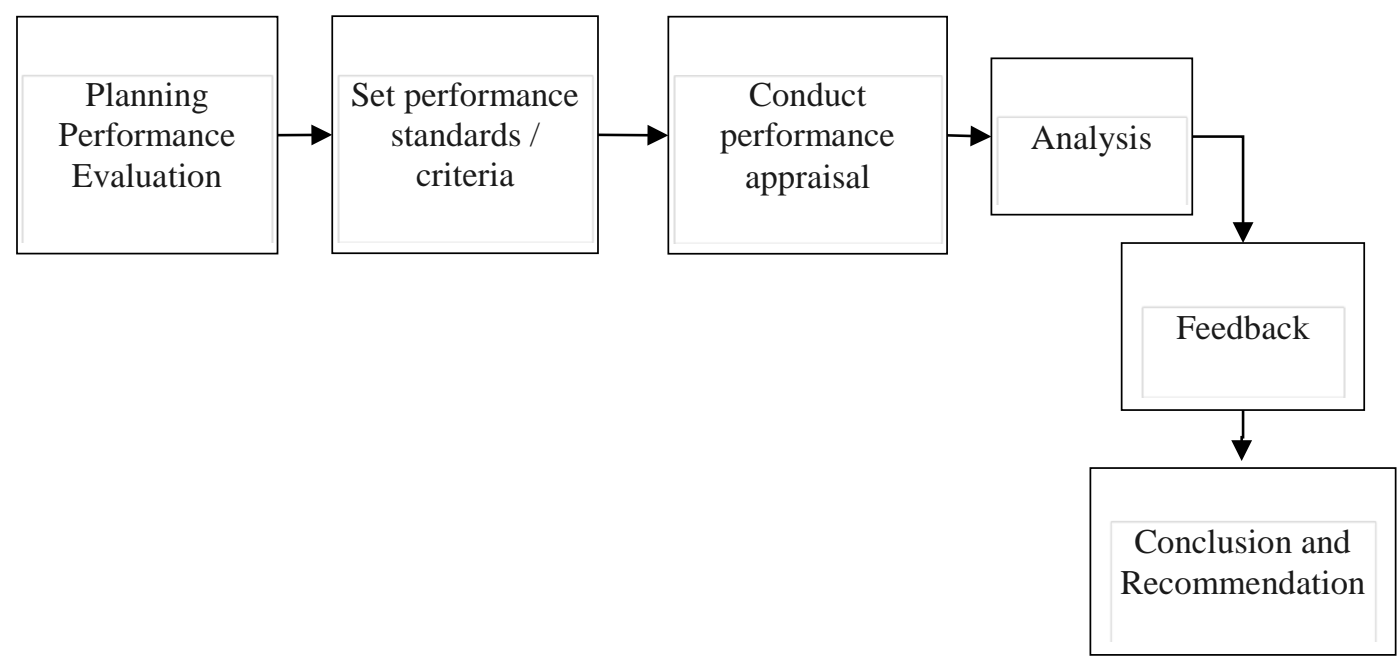

Figure 1. Design Performance Evaluation Research.

The instrument used to obtain information both primary data and secondary data related to the evaluation of teachers' performance, the researcher used written data in the form of documentation and also used the observation guidelines as the basis of performance appraisal through observation as well as interviews with respondents related to the research by giving a score.

The results of the assessment will be processed based on the criteria component assessment, with the final recapitulation, hence the formula:

$$
\mathrm{NA}=(\text { score } \mathrm{x} \text { 100\%) / maximum score }
$$

The final achievement and recapitulation scores were presented in percentages with categories: the 91 to 100 scores interpreted as excellent, the 76 to 90 scores interpreted as good, the 51 to 75 scores interpreted as enough and the scores below 50 interpreted as less [17]. 


\section{RESULTS OF THE RESEARCH}

\section{TEACHERS’ PERFORMANCE IN OPENING LESSONS}

Teachers' activity to open learning is the earliest activity in the learning process. The performance of teachers in opening lessons can be identified by the following criteria: (1) preparing students, (2) giving motivation and apperception, (3) explaining the basic competencies and objectives to be achieved, and (4) conveying the material coverage and explaining of activity description according to the syllabus or the readiness of teaching materials $[7,10]$.

Based on interviews and document analysis showed in opening lessons, teachers were still lacking in terms of providing motivation and apperception, lacking in providing objectives and material coverage. Furthermore, the teachers also did not adjust the teaching to the lesson plan. Teachers' performance in the opening lesson were $74,02 \%$ with good qualification, by assessing the how the teachers were in preparing students, doing motivation and apperception, explaining basic competence and objectives to be achieved, and conveying material coverage and explaining activity description according to the syllabus or the readiness of teaching materials.

Based on the age group, the teachers performance in opening the learning were as follow: (1) The teachers' performance in the age category of less than 26 years old achieved a good qualification of 78.16\% (2) The teachers' performance in the 26-30 years old age category were $67.63 \%$ (3) Teachers' performance in the 31-35 years old age category were $74.53 \%$ (4) Performance of teachers in the 36-40 years old age category were $81.25 \%$.

\section{TEACHERS' PERFORMANCE IN CONDUCTING CORE LEARNING ACTIVITIES}

The core activity stage in learning is a learning process to achieve basic competence. The core activities of learning are interactive, inspirational, fun and able to motivate students to actively participate and provide sufficient space so that students can take initiative, be creative and independent in accordance with their talents, interests and physical and psychological development.

The core learning activities and criteria are: (1) elaboration activities with the following criteria: (a) involving students in seeking information and learning from various sources; (b) using various learning approaches, media, and other learning resources; (c) involving students actively in any learning activity, and (d) facilitating students to do experiments in laboratories, studios, or the field. (2) exploration activities with the following criteria: (a) familiarizing students to write various materials through meaningful tasks such as students' scientific papers, (b) facilitating students through assignments or discussions to elicit new oral and written discussions, (c) Giving students the opportunities to think, analyze, solve problems, and act fearlessly, and (d) facilitating students in cooperative and collaborative learning. (3) confirmation activities with the following criteria: (a) facilitating students to make exploratory reports in both oral and written forms, individually or in groups, (b) facilitating students in exhibitions, tournaments, festivals, (c) 
facilitating students to present results Individual and group work, and (d) facilitating students to engage in activities that foster pride and confidence [10,18].

Analysis of the results of interviews and document showed that in conducting core activities of the combustion, the teacher had carried out the exploration well and had already involved students in finding information and learning from various sources. Teachers had not used a variety of learning approaches which suit the students' characters. Teachers had not used media and other learning resources well, had not involved students actively in every learning activity, and had not facilitated students in conducting experiments in the laboratory as well as in the field. In the exploration aspect, the teachers scored $74,43 \%$ with good qualification.

Teachers were still lacking in elaboration, such as did not encourage the students enough to get used to writing various materials through meaningful tasks such as scientific papers. Teachers also did not fully facilitate students through the assignment or discussion well, a were also still lacking in providing opportunities for students in analyzing and solving problems, and did not fully facilitate students in cooperative and collaborative learning. In the elaboration aspect, the teachers scored $69.50 \%$ with enough qualification.

Teachers were still lacking in conducting confirmation activities in learning, such as in providing feedback and reinforcement to all students, both the students who had to succeed and the ones who hadn't. Teachers were also still lacking in terms of facilitating students to reflect to gain learning experience. In the confirmation aspect, the teachers scored $67,44 \%$ with enough qualification.

Teachers still had not implemented the planned Lesson Plan (RPP) in their teaching. Teachers' performance in core learning activity was 68,79\% with enough qualification. Teachers' performance in core activities of learning by age group were as follow: (1) teachers' performance at age less than 26 years old were 66,67\%; (2) teachers' performance at age 26-30 years old were $60,94 \%$, (3) the performance of teachers at the age of $31-35$ years old were $66.54 \%$; (4) the performance of teachers at the age of $31-40$ years old were $68.75 \%$.

\section{TEACHERS’ PERFORMANCE IN CLOSING LEARNING SESSION}

In closing the lesson, the teacher were to guide students in making conclusions or summaries of learning, to conduct assessment to students or invite students to reflect on learning activities which had been done, to provide feedback on the results of assessment of learning, assigning tasks or follow up activities individually or in groups and to convey the material to be taught next. The teachers' performance in closing learning were observed with the following criteria: (1) making summaries or conclusions by reporting the outcome of the discussion, (2) reflecting or evaluating the activities which were already consistently and programmatically implemented, (3) planning follow-up activities in the form of learning, remedial, enrichment programs, counseling services, or individual or group assignments, and (4) submitting the next lesson plan [10].

Based on the findings of interviews and document analysis, the teachers had made summary of the material already taught, had already reflected on the activities that have been implemented, but were still lacking in planning follow-up in the form of remedial learning, enrichment program or with individual or group tasks, and were 
also lacking in conveying the next lesson plan to the students. Teachers' performance in closing learning were 68,01\% with enough qualification.

Furthermore, teachers' performance in closing learning were as follow: (1) teachers' performance in closing lesson at the age of less than 26 years old were $70,67 \%$; (2) teachers' performance at the age of $26-30$ years old were $63,75 \%$ (3) teachers' performance at the age of 31-35 years old were 69,58\%; (4) teachers' performance at the age of $31-40$ years old were $73,33 \%$.

\section{DISCUSSION}

Based on the results of the research it can be concluded: the teachers' performance in conducting the learning process were 71,33 with good qualification, teachers within the age group of $<26$ years old scored an average of 63,75, teachers within the age group of 26-30 years old scored an average of 69,58, teachers within the age group of 31-35 years old scored an average of 74.17 and teachers within the age group of 36-40 years old scored an average of 73.33. From the result also can be seen, the performance of teachers in opening lessons mostly were still lacking in providing student learning motivation contextually according to the benefits and application of teaching materials in everyday life. In the core learning activities, in the elaboration section, teachers did not provide opportunities for students to express and actualize themselves through meaningful activities and works [19, 20].

\section{RECOMMENDATIONS}

In opening learning, teachers should be able to provide motivation and apperception well, teachers should be able to explain the objectives and coverage of learning materials that will be taught well, teachers must adapt to the planned implementation of learning which has been prepared beforehand.

In carrying out the core activities, learning should be done interactively, inspiration, fun and motivate students to participate actively. The students can take initiative, be creative, and independent according to their talents, interests and physical and psychological development.

In closing the lesson, the teacher should guide the students to make conclusions or summaries of learning, assess students or invite the students to reflect on the learning activities that have been done. Provide feedback on the results of the learning assessment, give tasks or follow-up activities individually or in groups and convey the material to be taught next.

\section{REFERENCES}

[1] Rice, J. K. (2010). The Impact of Teacher Experience Examining the Evidence and Policy Implications, (August), 1-8.

[2] Si, H. (2011). Comparative Study of the New and Experienced Teachers ' Differences in the 
General Teaching of Mathematics, 4(2), 71-79.

[3] County, S., \& Oliver, J. (2005). A Comparison of the Perceptions between Novice and Veteran Teachers about the Teaching Profession in Elementary and Middle Schools in.

[4] Okas, A., Schaaf, M. Van Der, \& Krull, E. (2014). Novice And Experienced Teachers ' Views, 18(Krull 2002), 327-344. https://doi.org/10.3176/tr.2014.4.02

[5] Ramayulis. (2015). Dasar-dasar Kependidikan: Suatu Pengantar Ilmu Pendidikan. Jakarta: Kalam Mulia.

[6] Spilt, J. L., Koomen, H. M. Y., \& Thijs, J. T. (n.d.). Teacher Wellbeing: The Importance of Teacher - Student Relationships. https://doi.org/10.1007/s10648-011-9170-y

[7] Kimani, G. N., Kara, A. M., Njagi, L. W., \& Kara, A. (2013). Teacher Factors Influencing Students’ Academic Achievement In Secondary Schools In Nyandarua County , 1(3), 1-14.

[8] Sanjaya, W. (2006). Strategi Pembelajaran Berorientasi Standar Proses Pendidikan. Jakarta: Kencana Prenadamedia Group.

[9] Goverment. Permendiknas Nomor 41 tahun 2007 tentang Standar Proses Untuk Satuan Pendidikan Dasar Dan Menengah (2007). Indonesia.

[10]Zuzovsky, R., \& Aviv, T. (2005). Teachers Qualifications and Their Impact on Student Achievement Findings from TIMSS-2003 Data in Israel, (2001).

[11]Barnawi dan Mohammad Arifin. (2012). Kinerja Guru Profesional: Instrumen Pembinaan, Peningkatan, dan Penilaian. Jogjakarta: Ar-Ruzz Media.

[12] Campbell, J. P. (2005). Evaluating Teacher Performance In Higher Education: The Value Of Student Ratings.

[13] Truxillo, D. M. (n.d.). Age and Work Performance: Myths and Realities. Department of Psychology Portland State University. Retrieved from https://www.ohsu.edu/xd/research/centers-institutes/oregon-institute-occupational-healthsciences/outreach/upload/Truxillo.pdf

[14]Christian Göbel and Thomas Zwick. (2009). Age and Productivity - Evidence from Linked Employer Employee Data. (C. for E. E. R. (ZEW), Ed.). Mannheim.

[15]Homer, K. L., Murray, H. G., \& Rushton, J. P. (1989). Relation Between Aging and Rated Teaching Effectiveness of Academic Psychologists, (2), 226-229.

[16] Shinkfield, D. J. S. and A. J. (2007). Evaluation Theory, Models, \& Applications. San Francisco: Jossey-Bass.

[17] Djaali, P. M. (2008). Pengukuran dalam Bidang Pendidikan. Jakarta: PT Gramedia Widiasarana Indonesia.

[18] Khurshid, F., \& Ansari, U. (2012). Effects of Innovative Teaching Strategies on Students'Performance, 12(10).

[19] Goe, L. (2007). The Link Between Teacher Quality and Student Outcomes: A Research Synthesis, (October).

[20] Oliver, R. M., Reschly, D. J., \& Ph, D. (n.d.). Effective Classroom Management: Teacher Preparation and Professional Development. 